\title{
Characteristic of meat colour of different duck populations
}

\author{
GABRIELA HARAF'1, JULIUSZ KSIAZŻKIEWICZ2,3, JANINA WOŁOSZYN and ANDRZEJ \\ OKRUSZEK ${ }^{1}$
}

'Department of Animal Food Technology, Wroclaw University of Economics, Wrocław, Poland, ${ }^{2}$ Department of Farm Animal Genetic Resources Conservation, National Research Institute of Animal Production, Balice n. Kraków, Poland, ${ }^{3}$ Department of Bioengineering Branch Campus of the Faculty of Biotechnology, Rzeszów University, Kolbuszowa, Poland

\section{Abstract}

Out of 6 conservative flocks (Khaki Campbell - Kh1, Orpington - 01, Miniducks - K2, Polish Pekin - P33, Pekin originated from Danish - P8 and cross-breeds in Pekin type - SB) 60 female ducks were used for comparison (10 ducks in each group). Birds were slaughtered at 7 week of age.

The investigation of breast muscles covers: determination of the colour parameters $L^{*}$ (lightness), $\mathrm{a}^{*}$ (redness), $\mathrm{b}^{*}$ (yellowness), $\mathrm{C}$ (saturation), $\mathrm{h}^{\circ}$ (hue) and $\Delta \mathrm{E}$ (colour difference), total haem pigments' content (THP) including myoglobin ( $\mathrm{Mb})$, oxymyoglobin $\left(\mathrm{MbO}_{2}\right)$ and metmyoglobin (MMb) content. Sensory evaluation of raw muscles' colour intensity in 10 point scale and Principal Component Analysis (PCA) of all measured parameters were also performed.

Low THP and $\mathrm{MbO}_{2}$ were shown by Kh1 and P33 (THP: 3.79 and $3.74 \mathrm{mg} / \mathrm{g}, \mathrm{MbO}_{2}: 2.32$ and $2.46 \mathrm{mg} / \mathrm{g}$ respectively). They were also characterized by the highest $L^{*}$ value of the all flocks (45.27 and 44.25 respectively) $(P \leq 0.01, P \leq 0.05)$.

The Kh1 was evaluated by the sensory panel as the lightest (5.01 conventional units [CU]) $(P \leq 0.01)$. However P8 and K2 were assessed as darker than Kh1 and P33 (6.12 and $6.22 \mathrm{CU}$ vs. 5.01 and $5.71 \mathrm{CU})(P \leq 0.01, P \leq 0.05)$ and also had significantly higher pigments content ( 4.48 and $4.57 \mathrm{mg} / \mathrm{g}$ respectively) $(P \leq 0.01)$. Additionally $\mathrm{K} 2$ was characterized by the highest $\mathrm{MMb}$ content $(0.48 \mathrm{mg} / \mathrm{g})(P \leq 0.01)$, but this value is below the level that makes the colour undesirable. The $\Delta \mathrm{E}$ values between flocks were in the 1.02-2.86 range. With just few exceptions, flocks with $\Delta \mathrm{E}$ value higher than 2 , differed significantly in pigments content, $L^{*}$ parameter, and sensory panel scores. As regards the obtained results Kh1 and P33 appeared significantly lighter than P8 and K2. Kh1 and P33 had lower pigments content, higher $L^{*}$ value and were assessed by a sensory panel as having lower colour intensity than P8 and K2. PCA analysis confirmed ANOVA results and also indicated large total colour variation of the samples within breeds except of 01 muscles.

Keywords: duck, genetic reserve flocks, meat quality, meat colour

\section{Zusammenfassung}

\section{Merkmale der Fleischfarbe verschiedener Entenpopulationen}

Für die Untersuchung der Fleischfarbe wurden je 10 Enten von 6 verschiedenen bodenständigen Entenpopulationen und Genreserven im Alter von 7 Wochen geschlachtet. Einbezogen waren die Tierpopulationen Khaki Campbell (Kh1), Orpington (01), 
Miniducks (K2), Polish Pekin (P33), Peking 1978 aus Dänemark importiert (P33) und Kreuzungstiere im Pekingtyp (SB) als Nachfahren von 1977 aus England importierten Tieren. Es erfolgte die Erfassung zahlreicher Farbmerkmale am Brustmuskel der Tiere. Geringe Gesamthaempigment-(THP) und Oxymyoglobinwerte $\left(\mathrm{MbO}_{2}\right)$ wurden bei Kh1 und P33 beobachtet, die auch im Vergleich mit allen anderen Populationen die höchsten Farbwerte $\left(L^{*}\right)$ erreichten. Die P8 und K2 Population wiesen dunkleres Fleisch sowie signifikant höhere THP Werte auf. K2 war auch durch den höchsten Metmyoglobingehalt $(\mathrm{MMb})$ gekennzeichnet jedoch lag dieser Wert unterhalb der erwünschten Farbwerte. Die $\Delta \mathrm{E}$ Werte der Farbdifferenz zwischen den Populationen lagen bei den Rängen 1,02 bis 2,86. Mit nur wenigen Ausnahmen unterschieden sich Populationen mit $\Delta \mathrm{E}$ Werten größer als $2.0 \mathrm{im}$ THP Gehalt, den $\mathrm{L}^{*}$ - und den Sensorikwerten. Die erhaltenen Kh1 und P33 Populationen schienen offensichtlich hellere Probenwerte als P8 und K2 zu erreichen. Sie wiesen geringere Pigmentgehalte sowie höhere $L^{*}$-Werte und eine geringere Farbintensität auf als P8 und K2. Die Auswertungen ergaben mit Ausnahme der 01 eine große Variation der Farbwerte innerhalb der einzelnen Populationen.

Schlüsselwörter: Enten, Genreserve, Fleischqualität, Fleischfarbe

\section{Introduction}

Poland and other countries membership the United Nations signed the Convention on Biological Diversity at the World Summit in Rio de Janeiro in 1992. Some breeds of ducks were included in the national genetic resources programme, but not only because of the formal obligations but also for maintaining the reproducibility of old, local animal species and breeds for future generations. Conservative flocks are kept in Poland by sin situ « method since the 1970s. National Research Institute of Animal Production worked out the programme for the maintenance of genetic resources and determined diversity of reproduction and fleshiness traits between flocks.

There were a lot of research conducted to know better the individual traits of ducks populations among others determining of biochemical compounds of blood, eggs and meat, genetic parameters of ducks and changes of production value in the next generations maintained without selection (KSIĄŻKIEWICZ 2002). However data about functional traits of meat of the specific ducks are scarce and that is why the investigation on the technological quality of the ducks muscles is needed.

Among many quality traits of meat, colour has always been considered a very important feature. Colour is regarded as an indicator of meat freshness by many consumers, therefore can be the main element which influences purchasing behaviour. The impression of colour is caused by diffusion and absorption of light falling on the surface. However the shade of colour depends on kind and concentration of pigments. The relative proportions of myoglobin forms such as purple deoxymyoglobin (Mb), red oxymyoglobin $\left(\mathrm{MbO}_{2}\right)$ and brown metmyoglobin $(\mathrm{MMb})$ determine the colour of fresh meat. All factors affecting meat colour, in fact influence directly or indirectly on concentration and chemical state of myoglobin as well as physical structure of meat (MILLAR et al. 1996, RENERRE 1999, MANCINI and HUNT 2005). Colour depends on breed, age, sex of animal (KISIEL and KSIAZŻKIEWICZ 2004, WOŁOSZYN et al. 1997, WAWRO et al. 
2004), type of muscle (SKRABKA-BŁOTNICKA et al. 2002a), feeding, pre-slaughter treatment and stress (ROMBOLI 1995, FLETCHER et al. 1992), method of slaughter (BIANCHI et al. 2006), electrical stimulation (UIJTTENBOOGAART 1993), storage conditions (SKRABKABŁOTNICKA et al. 2002b). Colour can be shaped by combination of these and many other factors (RENERRE 1999). The aim of this paper was to characterize and compare the colour of ducks' muscles from different genotypes by determining, $L^{*}, a^{*}, b^{*}, C^{*}, h^{\circ}$ parameters, colour difference $\Delta \mathrm{E}$ between individual flocks, pigments' contents and performing sensory evaluation of meat colour intensity.

\section{Material and methods}

The study was conducted on breast muscles of 7 week - old female ducks from 6 flocks: Khaki Campbell (Kh1), Orpington (01), Miniduck (K2), Pekin originated from Danish (P8), Pekin (P33) as well as crossbreeds of ducks of English origin in Pekin type (SB) ( $n=10$ head for each flock) (Table 1). These unique on international scale populations of birds are kept by in situ method at the Waterfowl Genetic Resources Station of the National Research Institute of Animal Production in Dworzyska. The birds are characterized by very good health, resistance to variable, often adverse climatic conditions of region of their origin and good conversion of farm-produced feeds. Geese and ducks from conservative flocks provide unique material for studies of DNA polymorphism, blood serum proteins, embryo karyotypes and quality traits of eggs and meat. The fat of this birds is considered to be healthier than pork fat as it contains more unsaturated fatty acids and the meat is fine fibred. Another important characteristic of the waterfowl from conservative flocks is very good quality of down and feathers, which are used for the manufacture of sheeting fabrics (KSIĄŻKIEWICZ 2007).

Ducks were raised in controlled conditions in a poultry house until the 4th week of age and next on range of limited and sheltered area with straw bedding. Birds were fed ad libitum on the same compound feeds (Table 2). The diet until 3rd week of age contained $20 \%$ crude protein and $12.13 \mathrm{MJ}$ metabolizable energy (ME) and from 4th to 7 th week $16.5 \%$ crude protein and 12.34 MJ ME per $1 \mathrm{~kg}$ of feed.

Slaughter of birds and excising of breast muscles were made in a local slaughterhouse. The analysis of muscles was made $24 \mathrm{~h}$ after slaughter.

Haem pigments were extracted according to the procedure described by PIKUL (1993). The muscles were frozen at $-18^{\circ} \mathrm{C}$ for $24 \mathrm{~h}$ and subsequently (without thawing) cut in thin flakes after that were mixed. About $10 \mathrm{~g}$ of sample were homogenised with $50 \mathrm{~cm}^{3}$ of phosphate buffer (pH 6.8) at $4-6^{\circ} \mathrm{C}$ for $1 \mathrm{~min}$ at $3000 \mathrm{rpm}$. The homogenate was stored at $4-6^{\circ} \mathrm{C}$ for $1 \mathrm{~h}$. After the period the homogenate was centrifuged at $4000 \times \mathrm{g}$ for $10 \mathrm{~min}$. The supernatant was decanted and the remainder was extracted once more with $42.5 \mathrm{~cm}^{3}$ of the above mentioned buffer and centrifuged (in the same conditions as previously). The both supernatants were mixed and the volume was measured. The extract was centrifuged at $30000 \times \mathrm{g}$ for $1 \mathrm{~h}$ and filtered with the Whatman 1 paper filters. The absorbance was measured at 525, 545, 565 and $572 \mathrm{~nm}$ using the Hewlett Packard's Diode Array UV/VIS Spectrophotometer. The concentration of total haem pigments (THP) and relative concentration of: $\mathrm{Mb}, \mathrm{MbO}_{2}$ and $\mathrm{MMb}$ were calculated with the equations given by KRZYWICKI (1982). 
Table 1

Characteristics of experimental material

Beschreibung der Versuchspopulationen

Flock Duck's origin Characteristics

Kh1 Khaki Campbell:

Their feathers are brown in colour. Males' legs are orange coloured and originating from a parent stock imported from

France in 1978

(conservative).

females grey coloured. They are characterized by rather low weight compared with Pekin ducks (adult males $-1800 \mathrm{~g}$, females $-1700 \mathrm{~g}$ ). They are representing an egg type although they possess meat traits too. The number of laid eggs are high (156-144 eggs/laying period). Eggs have very high biological value, that's why the ducks have outstanding breeding performance. (KSIĄŻKIEWICZ 2002, 2003)

01 Orpington fauve (yellow variety):

Plumage is light brown with black and brown neck for males. Legs are light grey coloured. Beak is brown and olive green. Body weight of an progeny of a breeding stock bought in France in 1971 (conservative). adult male is $2050 \mathrm{~g}$ and female $1900 \mathrm{~g}$. Laying is $143-126 \mathrm{eggs} / \mathrm{laying}$ period, eggshells are cream coloured. It is representing a multipurpose type. They were used many times for mating with Mullards, Pekins, Wild ducks and Khaki Campbell. Their meat is characterized by high fibres fineness (KSIĄŻKIEWICZ 2002, 2003).

K2 Miniduck: WOŁOSZYN et al. (2006), WORLD WATCH LIST (2000)

crossbred of wild white mallards (Anas platyrhynchos L.) and light Pekin type ducks (conservative).

P33 Polish Pekin: the native and old indigenous breeding strain (conservative).

P8 Pekins of Danish origin: progeny of Pekin parents imported from Denmark in 1978 (conservative).

WOŁOSZYN et al. (2006), WORLD WATCH LIST (2000)

They are characterized by white plumage. Legs and beak are yellow and orange. Weight of adult birds range from 3200 to $3400 \mathrm{~g}$. Laying is 153 eggs in first and 135 in second performance period. These ducks are characterized by outstanding reproduction and meatiness traits (KSIĄŻKIEWICZ and KIEŁCZEWSKI 1999, KSIĄŻKIEWICZ 2002).

SB Crossbreeds of ducks from three conservative groups $A 1, A 2$ and $A 3$, which were progeny of Pekin ducks imported from England in 1977 Feathers of these ducks are white, legs are orange and yellow, and beak is yellow or pale pink. Adult birds weigh from $2900 \mathrm{~g}$ to $3100 \mathrm{~g}$. The birds are characterized by good health, high number of laid eggs (137 to 151 eggs/lying period), and very good musculature (KSIĄŻKIEWICZ 2002).

Table 2

Diet composition used in the trial

Futterzusammensetzung während der Versuchsdauer

\begin{tabular}{lcc}
\hline Ingredients & 1-21days & 22-49 days \\
\hline Wheat meal, \% & 72.8 & 57.6 \\
Soybean meal, \% & 17.0 & 10 \\
Barley meal, \% & 17.4 & - \\
Rapeseed oil, \% & 1.0 & 1.6 \\
Calcium carbonate, \% & 0.8 & 6.0 \\
Dicalcium phosphate, \% & 2.0 & 2.0 \\
Premix KB (vitamin-mineral premix), \% & 1.0 & 1.4 \\
Fish meal, \% & 5.4 & 4.0 \\
\hline
\end{tabular}


The colour parameters of the surface of muscles i.e. lightness $\left(\mathrm{L}^{*}\right)$, redness $\left(\mathrm{a}^{*}\right)$ and yellowness $\left(b^{*}\right)$ were determined by the Minolta CR-310 ChromaMeter; hue $\left(h^{\circ}\right)$ and chroma $\left(C^{*}\right)$ were calculated using the following equations:

$$
h^{0}=\operatorname{tg}^{-1}\left(\frac{b^{*}}{a^{*}}\right) \quad \text { and } \quad C^{*}=\left(a^{* 2}+b^{* 2}\right)^{\frac{1}{2}}
$$

while colour difference $(\Delta E)$ was calculated from formula:

$$
\Delta E=\left[\left(\Delta L^{*}\right)^{2}+\left(\Delta a^{*}\right)^{2}+\left(\Delta b^{*}\right)^{2}\right]^{\frac{1}{2}}
$$

The $\Delta \mathrm{L}^{*}, \Delta \mathrm{a}^{*}$ and $\Delta \mathrm{b}^{*}$ were differences between mean $\mathrm{L}^{*}, \mathrm{a}^{*}$ and $\mathrm{b}^{*}$ values for individual flocks.

Sensory evaluation of the raw muscles' colour and its intensity was conducted by the sensory panel using the Analsens NT programme with 10 point scale $(1$ - very light colour; 10 - very dark colour) (BARYŁKO 2000). Sensory panel had 7 trained testers. The intensity was expressed in conventional units (CU).

Statistical analysis was based on arithmetic means and standard deviation (SD). The effects of flock were analysed by one way analysis of variance (ANOVA) in a nonorthogonal scheme. Significant differences between the average values were determined by Duncan's multiple range test. Principal component analysis (PCA) was applied to all analysed parameters of colour. The statistical analysis was conducted with the Software System Statistica, version 7.1 (STATSOFT INC. 2006).

\section{Results}

The investigation established differences in examined parameters. Physicochemical properties of meat and results of sensory evaluation of raw muscles' colour are shown in Table 3.

Table 3

Haem pigments content, colour parameters and sensory evaluation of colour duckıs breast muscles

\begin{tabular}{|c|c|c|c|c|c|c|c|c|c|c|c|c|}
\hline \multirow{3}{*}{ Parameter } & \multicolumn{12}{|c|}{ Flock } \\
\hline & \multicolumn{2}{|c|}{$\mathrm{Kh} 1, n=10$} & \multicolumn{2}{|c|}{$01, n=10$} & \multicolumn{2}{|c|}{$\mathrm{K} 2, n=10$} & \multicolumn{2}{|c|}{$\mathrm{P} 8, n=10$} & \multicolumn{2}{|c|}{ P33, $n=10$} & \multicolumn{2}{|c|}{$\mathrm{SB}, n=10$} \\
\hline & Mean & SD & Mean & SD & Mean & SD & Mean & SD & Mean & SD & Mean & SD \\
\hline$\overline{L^{*}}$ & $45.27^{A}$ & 1.06 & $42.69^{\mathrm{Bb}}$ & 1.24 & $42.56^{\mathrm{BD}}$ & 1.30 & $42.82^{\mathrm{Bb}}$ & 1.50 & $44.25^{\mathrm{Ca}}$ & 0.94 & $42.72^{\mathrm{Bb}}$ & 1.55 \\
\hline$a^{*}$ & 16.69 & 1.15 & 17.22 & 0.59 & 16.99 & 0.67 & $17.65^{b}$ & 1.67 & $16.35^{\mathrm{a}}$ & 0.66 & 16.56 & 1.15 \\
\hline$b^{*}$ & $3.97^{\mathrm{Bb}}$ & 1.17 & $3.57^{c}$ & 1.15 & $4.56^{\mathrm{BDd}}$ & 1.12 & $3.59^{c}$ & 0.65 & $2.83^{\mathrm{Ca}}$ & 0.61 & $2.67^{A}$ & 1.16 \\
\hline$C$ & 17.17 & 1.08 & 17.59 & 0.79 & 17.61 & 0.79 & $18.02^{b}$ & 1.44 & 16.60 & 0.73 & $16.81^{\mathrm{a}}$ & 0.99 \\
\hline$h^{0}$ & $13.26^{\mathrm{b}}$ & 1.60 & $11.74^{c}$ & 0.91 & $14.98^{\mathrm{Bd}}$ & 1.04 & $11.44^{c}$ & 0.90 & $9.82^{\mathrm{Aa}}$ & 1.39 & $9.21^{\mathrm{Aa}}$ & 1.46 \\
\hline $\mathrm{Mb}, \mathrm{mg} / \mathrm{g}$ & $1.36^{\mathrm{EC}}$ & 0.04 & $1.34^{\mathrm{Ca}}$ & 0.05 & $1.52^{\mathrm{BDd}}$ & 0.11 & $1.58^{\mathrm{BDF}}$ & 0.06 & $1.24^{\mathrm{Ad}}$ & 0.05 & $1.48^{\mathrm{Bb}}$ & 0.05 \\
\hline $\mathrm{MbO}_{2}, \mathrm{mg} / \mathrm{g}$ & $2.32^{\mathrm{A}}$ & 0.08 & 2.53 & 0.09 & 2.57 & 0.15 & $2.76^{\mathrm{Bb}}$ & 0.10 & $2.46^{\mathrm{a}}$ & 0.07 & $2.80^{\mathrm{Bb}}$ & 0.14 \\
\hline $\mathrm{MMb}, \mathrm{mg} / \mathrm{g}$ & $0.11^{B}$ & 0.02 & $0.11^{\mathrm{B}}$ & 0.03 & $0.48^{\mathrm{A}}$ & 0.14 & $0.14^{\mathrm{B}}$ & 0.03 & $0.04^{B}$ & 0.01 & $0.05^{B}$ & 0.008 \\
\hline $\mathrm{THP}, \mathrm{mg} / \mathrm{g}$ & $3.79^{\mathrm{A}}$ & 0.13 & $3.98^{\mathrm{Ca}}$ & 0.12 & $4.57^{B D}$ & 0.37 & $4.48^{\mathrm{BD}}$ & 0.32 & $3.74^{\mathrm{A}}$ & 0.12 & $4.33^{\mathrm{Bb}}$ & 0.19 \\
\hline $\begin{array}{l}\text { Pink-red colour } \\
\text { intensity, CU }\end{array}$ & $5.01^{\mathrm{A}}$ & 0.75 & $6.07^{B}$ & 0.63 & $6.22^{\mathrm{Bb}}$ & 0.61 & $6.12^{\mathrm{Bb}}$ & 0.54 & $5.71^{\mathrm{Ba}}$ & 0.49 & $6.07^{B}$ & 0.51 \\
\hline
\end{tabular}
Hämpigmentgehalt, Farbmerkmale und Sensorikwerte des Brustmuskels

Mean carrying different superscripts in the same row differ significantly: ${ }^{\mathrm{a}-\mathrm{d}} P \leq 0.05^{\mathrm{A}}{ }^{\mathrm{A}-\mathrm{P}} P \leq 0.01, \mathrm{Mb}$ myoglobin, $\mathrm{MbO}_{2}$ oxymyoglobin, Mb metmyoglobin, THP total haem pigments, SD standard deviation, CU conventional unit 
Table 4

Colour differences $(\Delta \mathrm{E})$ between individual flocks

Farbunterschiede zwischen den Populationen

\begin{tabular}{lrrrrrr}
\hline & Kh1 & O1 & K2 & P8 & P33 & SB \\
\hline Kh1 & & 2.66 & 2.78 & 2.65 & 1.56 & 2.86 \\
O1 & 2.66 & & 1.02 & 0.44 & 1.93 & 1.11 \\
K2 & 2.78 & 1.02 & & 1.20 & 2.50 & 1.94 \\
P8 & 2.65 & 0.44 & 1.20 & & 2.07 & 1.42 \\
P33 & 1.56 & 1.93 & 2.50 & 2.07 & & 1.55 \\
SB & 2.86 & 1.11 & 1.94 & 1.42 & 1.55 & \\
\hline
\end{tabular}

The data in Table 3 show that the Kh1 and P33 muscles were significantly higher in L* $(P \leq 0.01, P \leq 0.05)$ than the rest of the flocks. The P33 $(P \leq 0.05)$ was characterized by higher $a^{*}$ value than P8 $(P \leq 0.05)$, however K2 breast muscles showed higher $b^{*}$ than SB and P33 $\left(P \leq 0.01, P \leq 0.05\right.$ ). The $C^{*}$ values ranged from 16.60 (for $P 33$ ) to 18.02 (for $P 8$ ) and alike in the case of $\mathrm{a}^{*}$, difference between these two values was statistically significant at $P \leq 0.05$. The $h^{\circ}$ parameter varied from 14.98 to 9.21 and the differences were significant similarly to the differences in $b^{*}$.

The $\Delta \mathrm{E}$ values indicate that $\mathrm{Kh} 1$ muscles' colour differed much from other flocks' colour, except for P33. The $\Delta \mathrm{E}$ value between $\mathrm{Kh} 1$ and P33 was 1.56 and between $\mathrm{Kh} 1$ and other flocks from 2.86 to 2.65 (Table 4).

As regards the total haem pigments' content (THP), breast muscles can be divided in two groups. The P33, Kh1 and 01 belong to a group with lower THP $(3.74,3.79$ and 3.98 $\mathrm{mg} / \mathrm{g}$ respectively); however SB, P8 and K2 had higher THP $(4.57,4.48$ and $4.33 \mathrm{mg} / \mathrm{g}$ respectively). Differences between these two groups are statistically significant at $P \leq 0.01$ and $P \leq 0.05$.

Myoglobin content (Mb) in breast muscles ranged from $1.24 \mathrm{mg} / \mathrm{g}$ (for P33) to 1.58 $\mathrm{mg} / \mathrm{g}$ (for P8). The P33 and 01 showed significantly higher Mb content than SB, K2 and P8 (1.24 and $1.34 \mathrm{mg} / \mathrm{g}$ vs. $1.48,1.52$ and $1.58 \mathrm{mg} / \mathrm{g}$ respectively). Oxymyoglobin content $\left(\mathrm{MbO}_{2}\right)$ varied from $2.32 \mathrm{mg} / \mathrm{g}$ to $2.80 \mathrm{mg} / \mathrm{g}$. The $\mathrm{Kh} 1$ and $\mathrm{P} 33$ had significantly higher $\mathrm{MbO}_{2}$ content than $\mathrm{P} 8$ and $\mathrm{SB}$ ( 2.32 and $2.46 \mathrm{mg} / \mathrm{g}$ vs. 2.76 and $2.80 \mathrm{mg} / \mathrm{g}$ respectively) $(P \leq 0.01, P \leq 0.05)$. Metmyoglobin content (MMb) amounted from $0.04 \mathrm{mg} / \mathrm{g}$ to $0.48 \mathrm{mg} / \mathrm{g}$. The highest MMb content was showed by K2 $(P \leq 0.01)$ but this value didn't exceed content that makes the colour undesirable. Taking into consideration the obtained results oxymyoglobin was predominant in the duck muscles.

As regards the sensory evaluation - colour of the meat was recognised as pink - red and the surface' colour intensity scores given for breast muscles ranged from 5.01 to 6.22 CU. The Kh1 was assessed as the lightest (5.01 CU) $(P \leq 0.01)$. The notes for P8 and K2 $(6.12$ $\mathrm{CU}$ and $6.22 \mathrm{CU}$ respectively) were significantly higher than for $\mathrm{P} 33(5.71 \mathrm{CU})$ at $P \leq 0.05$.

The principal component analysis (PCA) was performed on the all measured parameters of duck meat colour. Table 5 contains the loadings for the first three principal components (PC) with their variances. The two first PCs accounted for $56.2 \%$ of the total variance. The $\mathrm{PC} 1$ explained for $35,09 \%$ of the variance and has high positive loadings for THP, $\mathrm{Mb}$ and $\mathrm{MbO}_{2}$ content, $\mathrm{a}^{*}$ and $\mathrm{C}$ parameter as well as negative loadings for $\mathrm{L}^{*}$. The PC2 accounts for $21.09 \%$ of the total variance and is associated with $b^{*}$ and $h^{\circ}$ value (Figure 1). 
Table 5.

Loadings for the first three PCs

Analysenwerte für die ersten drei Hauptkomponenten

\begin{tabular}{lrrr}
\hline & $P C 1$ & $P C 2$ & $P C 3$ \\
\hline $\mathrm{L}^{*}$ & -0.56 & -0.34 & 0.42 \\
$\mathrm{a}^{*}$ & 0.67 & -0.12 & -0.62 \\
$\mathrm{~b}^{*}$ & 0.38 & -0.86 & 0.16 \\
$\mathrm{C}$ & 0.70 & -0.30 & -0.54 \\
$\mathrm{~h}^{\circ}$ & 0.29 & -0.84 & 0.31 \\
$\mathrm{Mb}$ & 0.79 & 0.27 & 0.26 \\
$\mathrm{MbO}_{2}$ & 0.59 & 0.43 & 0.41 \\
$\mathrm{MMb}$ & 0.37 & -0.28 & 0.17 \\
$\mathrm{THP}$ & 0.84 & 0.26 & 0.44 \\
$\mathrm{Cl}$ & 0.46 & 0.18 & -0.01 \\
\hline
\end{tabular}

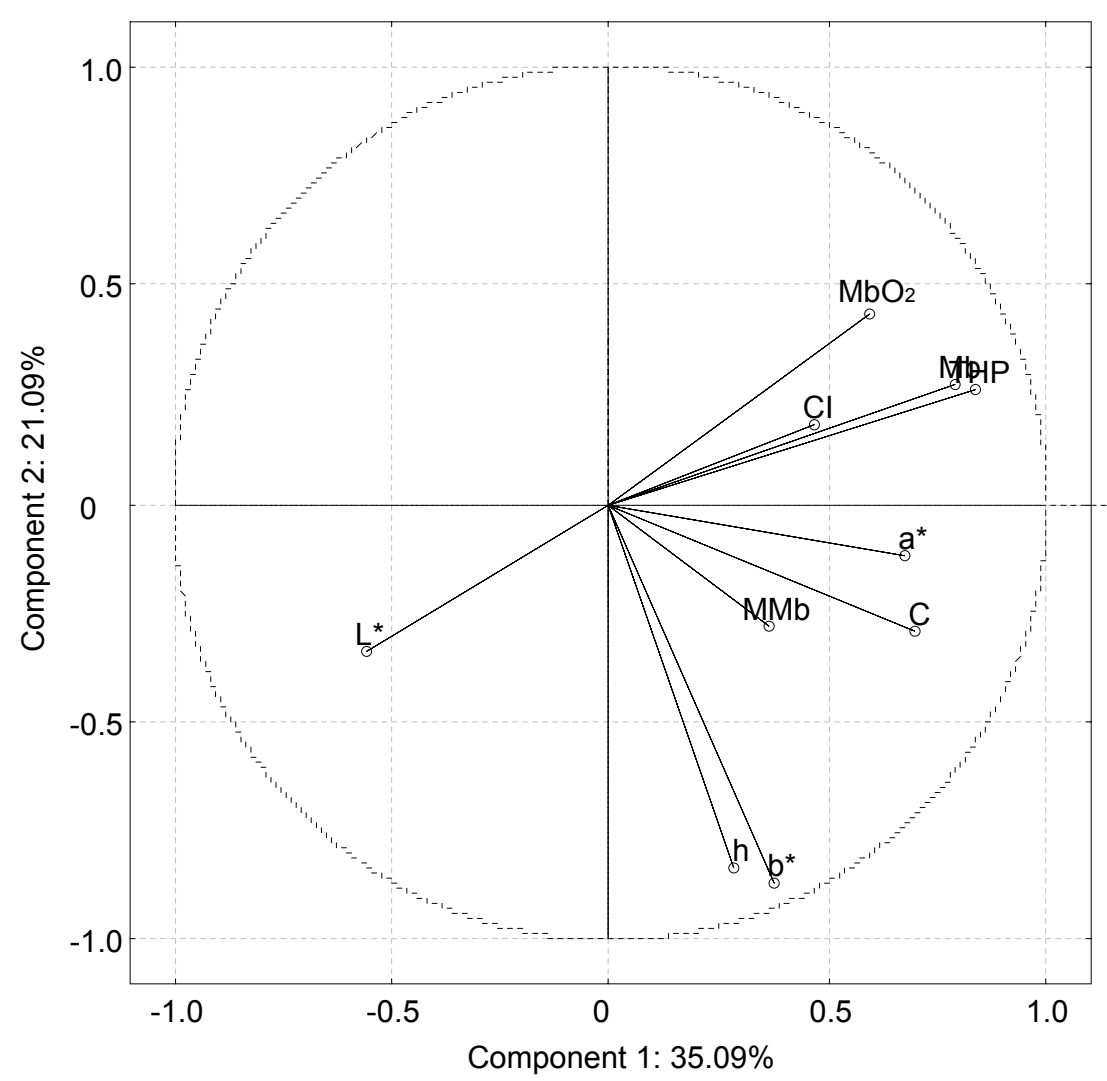

Figure 1

Loadings for the two first PCs (PCA of all analysed duck meat colour parameters)

Analysenwerte der ersten zwei Hauptkomponenten aller Farbparameter 


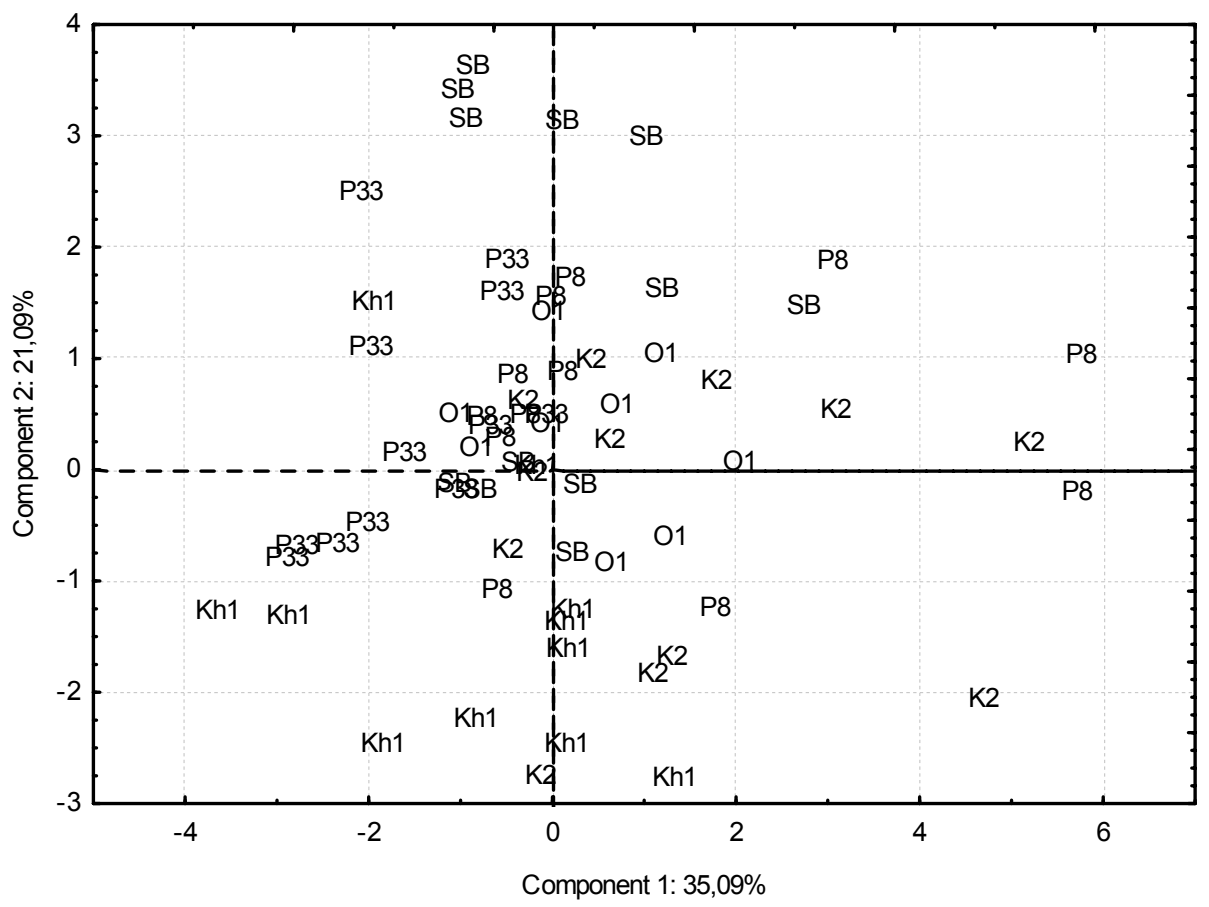

Figure 2

Scores for the two first PCs

Wertediagramm für die ersten zwei Hauptkomponenten

The score plot (Figure 2) shows the location of the samples in the multivariate space of two first PCs. It can be seen that samples were not homogeneous in colour also within the genotypes. There is no clear separation between these breeds. The parts of the samples overlap each other, so it means that they are similar. However it can be noted that some samples gathered in different places of a score plot, so they were different what resulted in statistically significant differences in colour between breeds. The Kh1 and P33 muscles differ much from K2 and P8. Samples to the right in the score plot have a large value for response variables to the right in the loading plot (NAES et al. 1996). According to this rule $\mathrm{K} 2$ and P8 samples, situated on the right, are characterized by high pigments content, low $\mathrm{L}^{*}$ and high $\mathrm{a}^{*}$ and $\mathrm{C}$ parameter. Kh1 and P33 situated opposite had low pigments concentration, high $L^{*}$ value and relatively low $\mathrm{a}^{*}$ and $C$ values. Considerable part of SB samples is concentrated at the top of the scores plot. It is caused by low $b^{*}$ and $h^{\circ}$ parameters values. It seems that 01 muscles had the most moderate traits and were the most homogenous in colour.

\section{Discussion}

Values of $L^{*}$, $a^{*}$ and $b^{*}$ reported by KISIEL and KSIĄŻKIEWICZ (2004) for K2 and P33 were somewhat different than results obtained by the authors of this paper, but the revealed differences are the same - P33 had significantly higher $L^{*}, a^{*}$ and $b^{*}$ colour parameters values than $\mathrm{K} 2$. 
SKRABKA-BŁOTNICKA et al. (2003) reported similar values of $L^{*}{ }_{24 \mathrm{~h}}$ for $\mathrm{K} 2$ and P33 drakes (42.2 and 43.6 respectively) but higher in $a^{*}$ and $b^{*}$ value (19.4 and 6.7 for K2; 19.4 and 5.7 for P33 respectively). Lower $L^{*}(41.14)$ and $a^{*}(11.72)$ and much higher $b^{*}(12.61)$ in breast muscles of Mullards were found by BAEZA et al. (1999). SKRABKA-BŁOTNICKA et al. (2002a) obtained for Muscovy ducks' breasts somewhat lower $L^{*}$ (42.27) but higher $a^{*}$ (20.99) and $b^{*}$ (4.83) compared to the examined muscles. ROMBOLI et al. (1997) tested breast muscles of heat stressed Muscovy ducks and found higher $h^{\circ}$ (17.89) and $b^{*}(5.71)$ as well as lower $L^{*}(40.43)$ than all examined duck muscles. Obtained by these authors $C$ (18.37) and $a^{*}(17.44)$ values were similar to P8. WOŁOSZYN (2002) carried out research on breasts of force fattened Mullards and the results were higher in $a^{*}(21.47)$ and $b^{*}$ (6.86) than present findings but $L^{*}$ were much the same to Kh1 (45.18). In the same publication can be found somewhat lower THP $(3.20 \mathrm{mg} / \mathrm{g})$ and $\mathrm{Mb}$ content $(1.25 \mathrm{mg} / \mathrm{g})$ as well as much lower $\mathrm{MbO}_{2}(1.13 \mathrm{mg} / \mathrm{g})$ and $\mathrm{MMb}$ content $(0.78 \mathrm{mg} / \mathrm{g})$. SKRABKABŁOTNICKA et al. (2002a) investigated among other things haem pigments content in breasts of Mullards and gained higher THP (4.63 mg/g), Mb (1.82 mg/g) and MMb $(0.97 \mathrm{mg} / \mathrm{g})$ but lower $\mathrm{MbO}_{2}(1.65 \mathrm{mg} / \mathrm{g})$ than values obtained in this paper for each individual flock.

PIKUL et al. (1982, 1987) and NIEWIAROWICZ et al. (1986) founded THP values in similar range of THP in Pekin breasts (from 3.68 to $4.54 \mathrm{mg} / \mathrm{g}$ ). Sightly lower pigments content in Muscovy muscles was stated by PIKUL et al. (1987) $(3.68 \mathrm{mg} / \mathrm{g})$. ALEXIEVA et al. (1998) found also lower haem pigments in 8 weeks old White Pekin and Muscovy ducks ( $2.75 \mathrm{mg} / \mathrm{g}$ and $3.26 \mathrm{mg} / \mathrm{g}$ respectively).

Some relation can be noticed comparing the significant differences in colour parameters and pigments content with the $\Delta \mathrm{E}$ values. If the $\Delta \mathrm{E}$ equalled more than 2 , there is a real chance of occurring significant difference between these groups within traits analysed in the paper. Only few exceptions to the rule can be found.

A similar situation occurs when comparing $\Delta \mathrm{E}$ values with sensory evaluation of colour intensity results - flocks which had $\Delta \mathrm{E}$ more than 2 , were evaluated as different in colour.

This rule didn't work only in the case of $\Delta E$ for $K h 1$ and P33 $\left(\Delta E_{K h 1, P 33}=1.56\right)$. These groups didn't differ as regards pigments content and $L^{*}$ parameter but despite the fact, sensory panel observed the difference in colour.

These results can be explained by a fact that, measurement of sensory traits by human senses and instrumentally ( $L^{*}, a^{*}, b^{*}$ parameters) cannot be substituted. The reason for it is that, the results of instrumental methods are related to physical stimuli creating sensations, while sensory evaluation informs about sensations caused by the stimuli. Therefore both methods of measurement sensory characteristics of foods are complementary but cannot be substituted (BARYŁKO-PIKIELNA 1998).

On the basis of gained results can be concluded that muscles of Kh1 and P33 are significantly lighter than P8 and K2. Kh1 and P33 muscles had less pigments, high L* value and were sensory evaluated as lighter than other muscles. The K2 and P8 showed high pigments content, low $L^{*}$ and sensory panel assessed them as darker than Kh1 and $\mathrm{P} 33$. Additionally it is confirmed by the $\Delta \mathrm{E}$ values for these flocks which are in the 2.1-2.7 range. Furthermore $\mathrm{K} 2$ muscles were more yellow than others due to high $\mathrm{h}^{\circ}$ value. The results of PCA analysis were in accordance with the obtained ANOVA results. High 
heterogeneity in colour of the analysed muscles was stated. The 01 showed the least variation in total colour.

\section{References}

Alexieva D, Genchev A, Drbohlav V (1998) Meat quality of intensively fattened ducks-broilers. Proc. of 10th European Poultry Conference. Jerusalem, 641-3

Baeza E, Salichon MR, Marche G, Wacrenier N.; Dominguez B, Culioli J (1999) Age and sex effects on the technological and chemical characteristics of mule duck meat. Proc 1th World Waterfowl Conf, Taiwan, 531-7

Baryłko M (2000) Digital systems and software. Caret, Gdańsk [in Polish]

Baryłko-Pikielna N (1998) Sensory analysis in assurance of food quality. Przem Spoż 12, 25-8 [in Polish]

Bianchi M, Petracci M, Cavani C (2006) Gas stunning and quality characteristics of turkey breast meat. World's Poultry J Sci, Supplement, Vol 62, Proc of 12th Europ Poultry Conf, Verona, 268

Fletcher DJ, Schreurs FJG, Uijttenboogaart TG (1992) Chemically induced stress and post mortem physiology in broiler chickens. Proc 19th World's Poultry Congr Amsterdam, 365-8

Kisiel T, Książkiewicz J (2004) Comparison of physical and qualitative traits of meat of two Polish conservative flocks of ducks. Arch Tierz 47, 367-75

Krzywicki K (1982) The determination of haem pigments in meat. Meat Sci 7, 29-36

Książkiewicz J (2002) The use of biodiversity of ducks for ecological backyard breeding. Wyd Inst Zoot Kraków, 4-9 [in Polish]

Książkiewicz J (2003) Comparison of reproduction and carcass traits in light type of ducks of four conservative flocks over eight generations. Arch Tierz 46, 377-89

Książkiewicz J (2007) Native genetic resources of waterfowl. Proc Int Sci Conf: Conservation of animal genetic resources in Poland and in Europe - achievements and dilemmas. Kraków, 54

Książkiewicz J, Kiełczewski K (1999) Time trends in meatiness traits in ducks of conservative groups. Adv Agricult Sci 6, 39-52

Mancini RA, Hunt MC (2005) Current research in meat color. Meat Sci 71, 100-21

Millar SJ, Moss BW, Stevenson MH (1996) Some observation on the absorption spectra of various myoglobin derivatives found in meat. Meat Sci 42, 277-88

Naes T, Baardseth P, Helgesen H, Isaksson T (1996) Multivariate Techniques in the Analysis of Meat Quality. Meat Sci 43 Suppl, 135-49

Niewiarowicz A, Pikul J, Czajka P (1986) Content of myoglobin and hemoglobin in different types of poultry meat. Fleischwirtsch 66, 1281-2 [in German]

Pikul J (ed) (1993) Technological evaluation of raw materials and poultry products. AR Poznań 87-9 [in Polish]

Pikul J, Niewiarowicz A, Pospieszna H (1982) Content of haem pigment in different types of poultry meat. Fleischwirtsch 62, 900-5 [in German]

Pikul J, Doruchowski W, Tański S, Reksiński T (1987) The comparison of carcass yield and cutability as well as chemical composition and technological traits of Muscovy and Pekin ducks meat. Zesz Nauk Drob COBRD, Poznań 4, 73-92 [in Polish]

Renerre M (1999) Biochemical basis of fresh meat colour. Proc 45th Inter Congr of Meat Science and Technology. Yokohama, 344-51

Romboli I (1995) Production factors and Meat Quality in Waterfowl. Proc of 10th Europ Symp on Waterfowl. Halle/Saale, 310-20

Romboli I, Russo C, Zanobini S (1997) Effect of dietary vitamin E on chemical composition and meat colour in heat stressed muscovy duck. Proc of 13th Europ Symp on the Quality of Poultry Meat, Poznań, 205-211

Skrabka-Błotnicka T, Orkusz A, Wołoszyn J (2002a) The characteristic of the breast and leg muscles colour from Muscovy ducks. Proc 45th Inter Congr of Meat Science and Technology. Rome, Vol 2, 538-9

Skrabka-Błotnicka T, Przysiężna E, Wołoszyn J (2002b) The changes in some functional and sensory attributes in vacuum packed Mullard muscles as effect of ageing in chilling temperature. Arch Geflügelk 66, 1-6

Skrabka-Błotnicka T, Książkiewicz J, Orkusz A, Wołoszyn J, Kisiel T (2003) Evaluation of normal, PSE- and DFD-like condition in drakes Quality of Poultry Meat. Saint-Brieuc, 112-6 
StatSoft Inc (2006) STATISTICA (data analysis software system), version 7.1

Uijttenboogaart TG (1993) Key influences of post mortem treatments. Proc of 11th Europ Symp on the Quality of Poultry Meat. Tours, 21-4

Wawro K, Wilkiewicz - Wawro E, Kleczek K, Brzozowski W (2004) Slaughter value and meat quality of Muscovy ducks, Pekin ducks and their crossbreds, and evaluation of the heterosis effect. Arch Tierz 47, 287-99

Wołoszyn J (2002) The physicochemical and technological characteristic of muscles from force fed ducks. Wyd AE Wrocław, 145 [in Polish]

Wołoszyn, Skrabka-Błotnicka T, Przysiężna E (1997) The characteristic of leg muscle colour from force fattened ducks. Proc of 13th Europ Symp on the Quality of Poultry Meat, Poznań, 338-43

Wołoszyn J, Książkiewicz J, Skrabka-Błotnicka T, Haraf G, Biernat J, Kisiel T (2006) Comparison of amino acid and fatty acid composition of duck breast muscles from five flocks. Arch Tierz 49, 194-204

World Watch List For Domestic Animal Diversity (2000) FAO, UNDP, 3rd ed, 3 - 73, 351

Received 3 April 2008, accepted 4 April 2009.

Corresponding author:

M.Sc. GABRIELA HARAF

email: gabriela.haraf@ue.wroc.pl

Wroclaw University of Economics, Department of Animal Food Technology, Komandorska 118/ 120, 53345 Wroclaw, Poland 